FOLIA SCANDINAVICA

VOL. 15 POZNAŃ 2013
LITERATURE

DOI: $10.2478 /$ fsp-2013-0005

\title{
MINNEPROBLEMATIKKEN \\ I LARS SAABYE CHRISTENSENS LYRIKK
}

\author{
- ANALYSE AV JEG-PERSONENS MINNER \\ I LYS AV MEMORY STUDIES
}

\section{ALEKSANDRA REGINA WILKUS}

Adam Mickiewicz University in Poznań

\begin{abstract}
The purpose of this article is to perform an analysis of Lars Saabye Christensen's poem 'Nocturne' from the perspective of Memory Studies. Recollections and the past are not simply the main issues of the literary work, but also provide a basis that can be used as a conceptual apparatus in one's interpretative work. That is exactly what occurs in the relatively new study field that focuses on cultural aspects of literature, i.e. Memory Studies. Through an indepth analysis of the language, stylistic measures, and with reference to Aristotle, I focus on the mechanisms that are in control of the lyrical subject's memory. Just as essential are P. Ricoeur's reflections on location and spatiality as well as A. Assman's postulates that enable to describe objects and places as having a memory. The application of the ideas of Memory Studies as a methodological tool allows to determine the lyrical situation including the lyrical subject's internal states.
\end{abstract}

\section{INNLEDNING}

I løpet av siste 10 år har det oppstått en relativt ny retning i litteraturforskningen som opprinnelig knyttes til et større forskningsfelt, nemlig studier om hukommelse. Selv om minneproblematikken var et bredt diskutert emne allerede $\mathrm{i}$ antikken, anlegger moderne 
litteraturforskere et nytt perspektiv i måten de utforsker den på. I lys av Aristoteles og Platon sine teorier kommer det til syne et stadig nyere bergepsapparat som tydelig både henviser til tradisjonen og samtidig legger vekt på problemene som er forbundet med historiske hendelser og menneskets samtidssituasjon. Artikkelens formål er å presentere en del av resultatene som utarbeides i masteroppgaven Det lyriske jeg-ets hukommelse og minner i Lars Saabye Christensens dikt. Der prøver jeg å utforske sammenhenger mellom det talende jeg-et og studier av minner, hvor fortolkningen baserer seg på MEMORY STUDIES-teori. Før jeg diskuterer hvilke konklusjoner vi kan komme til gjennom den slags analyse, skal det først klarlegges hvilke studiefelter Memory Studies egentlig omfatter. Det er nødvendig for etterpå å vise hvordan man kan bruke teorien i praksis, og på hvilken måte begrepsapparatet kan nyttes i fortolkningen av Lars Saabye Christensens dikt "Nocturne" (1976: 77).

Man kan spørre seg hvorfor det akkurat er minneproblematikken som synes å være så interessant $\mathrm{i}$ forhold til Saabye Christensens lyrikk. Å vende oppmerksomheten mot hukommelse og minner lar leseren gå dypere inn i det lyriske jeg-ets indre verden og dets skjulte opplevelser. I utgangspunktet muliggjør den slags analyse å kunne beskrive jeg-ets aktuelle ståsted, det vil si subjektets identitet, samt dets forhold til for-, nå- og fremtiden. Saabye Christensen er forfatteren som for øvrig selv svarer på spørsmålet om sin inspirasjon med følgende ord:

Marcel Proust betyr veldig mye for meg, som han sikkert også gjør for en rekke andre forfattere. $\mathrm{Og}$ erindringen er et viktig element i skrivingen min. Men da forstått som bevissthet, dette at man husker sitt liv. (Larsen 2004:1)

Samtidig bør man ha i tankene det faktum at Saabye Christensen veldig sjelden først og fremst verdsettes på grunn av sine diktsamlinger. På topplisten (Kverndokken 2001:69f.) over de beste norske romanbøkene plasserer blant annet Amatøren (1977), Beatles (1984), Herman (1988), Bly (1990), Gutten som ville vare en av gutta (1992) og Halvbroren (2001) seg, men Saabye Christensen debuterte vel med diktsamlingen Historien om Gly (1976) og mottok for denne Tarjei Vesaas sin debutantpris samme år (Vatne 1998:113). Når det er snakk om utgivelsestall, har Saabye Christensen hittil skrevet rundt 15 diktsamlinger. Til tross for denne mengden nevner litteraturkritikere noen særtrekk som gjelder for hele lyrikken hans. Det er nemlig et enkelt, nesten lakonisk språk og fokuset på det hverdagslige som regnes for Saabye Christensens kjennetegn (Vold 2004). Ingunn Økland skriver imidlertid i artikkelen Fortelleren overdøver poeten om forfatterens nesten jordnære estetikk, som på den ene side svarer til hans billedskapende evner, og som også virker ganske upretensiøs (Haagensen 1998). Vi skal altså utelukkende se 
på en liten del av en stor forfattervirksomhet, men for å være klar over hvilken skikkelse man har å gjøre, kan vi minnes Alte Næss' treffende ord:

Av og til kan den overveldede leser forledes til å tro at Lars Saabye Christensen må være et psevdonym for en hel gruppe iherdige skribenter: en rockpoet, en modernistisk lyriker, en filmmanus-forfatter, en entusiastisk antologiredaktør, en krimforfatter, en romanskribent med usvikelig sans for den bedre, godt fortalte historie, en finslepen novellist.... (Næss 1993:1)

Poenget med denne oversikten over Saabye Christensens diktning har nettopp som formål å vise leseren den relativt dårlig kjente siden av forfatterskapet, som samtidig er så verd å se litt nærmere på, særlig hvis man har for øyet forfatterens egentlige karrierestart.

\section{MEMORY STUDIES - RØTTER OG HOVEDPROBLEMER}

Ideen om å kombinere utforskningen av Saabye Christensens dikt med studier av erindringens mekanismer har imidlertid flere grunner enn bare det forfatteren selv sier om sitt motivvalg ${ }^{1}$. I faglig litteratur om hukommelsens forskjellige kategorier får vi vite at til de hyppigst omtalte emnene hører deriblant begreper som sosiologisk hukommelse, kollektiv og/eller felles hukommelse og historisk hukommelse (Saryusz-Wolska 2011:24). De to siste artene assosieres oftest med rent historiske hendelser og opplevelser som hadde store konsekvenser for allmennheten, eksempelvis andre verdenskrig og jødeutryddelser. I moderne tid har hukommelsens status likevel endret seg litt etter litt, mest grunnet tilkomsten av nye generasjoner, hvor tilegnelsen av erfaring ikke lenger preges like sterkt av historien som tidligere. Det er trolig derfor minnestudiene er på vei mot å rette større fokus på et enkelt menneske og dets individuelle erindring $\mathrm{i}$ forbindelse med sivilisasjons-kulturelle fremskritt. I begge kontekstene kan dermed Memory Studies betraktes som en interessant teori innenfor humanistiske fag, inkludert litteraturvitenskap.

Først er det nødvendig å nevne noen kjennetegn og emnefelter som opprinnelig knyttes til minnestudiene. Det skal nemlig hjelpe oss til å forstå hva vi kommer til å påvise i forhold til Saabye Christensens lyrikk og hva leseren følgelig bør være oppmerksom på i selve leseakten. Generelt sett lar spørsmålene som Memory Studies oftest stiller, formuleres slik: Hvordan forholder mennesker seg til fortiden? Hvordan påvirker minnene vår felles eksistens og samhandling med andre (Dessingué 2010:9)? Herved belyses kun noen av de viktigste problemene som er utgangspunktet for dette relativt nye

\footnotetext{
${ }^{1}$ Se: det første sitatet.
} 
fag- og forskningsfeltet. Navnet Memory Studies finner man for første gang i anledning utgivelsen av tidsskriftet "Memory Studies" i 2008 (Śnieżka 2011:7f.). I forordet til artikkelsamlingen Flerstemte minner skriver Dessingués:

[Memory Studies er] en kompleks arena som åpner seg for mangfoldige fagdisipliner (bl.a. antropologi, historie, filosofi, psykologi, språkvitenskap, didaktikk og estetikk) sammen med en variert metodologisk tilnærming (bl.a. fenomenologisk, hermeneutisk, tekstanalytisk, kontekstanalytisk, komparativ og historisk). (Dessingués 2011:9)

Memory Studies er, som vi ser, en tverrfaglig disiplin, og den utvikler seg stadig i flere retninger. Man kan dessuten verdsette dette fagfeltet på grunn av dets røtter, og da hevder teoretikere som blant andre Jan Assmann, Aleida Assmann, Alexandre Dessingué, Astrid Erll, Renate Lachmann, Paul Ricoeur, Magdalena Saryusz-Wolska og Frances Yates at Memory Studies bare delvis er innovative, for de baserer seg også på gamle antikke tradisjoner. Flere forskere henviser nemlig $\mathrm{i}$ sine tekster til Aristoteles og Platon sine overveielser, og bygger dermed teorier på direkte og indirekte analogier til de klassiske kildene. Dette skal også bli synligere når vi skal nærme oss fortolkningen av diktet "Nocturne", hvor hovedbegreper og ideer belyses og forklares.

Like viktig er det å understreke at historisk forskning ikke er inkludert i minnestudienes forskningsområde. Poenget er nettopp å fjerne seg fra den historiske diskursen for å se fortiden i et nytt lys. Saryusz-Wolska (2011:23) og Śnieżko er enige om at utgivelsen av tidsskriftet Memory Studies gjør det mulig å skille forskningen fra det rent historiske perspektivet. Denne viktige forskjellen på erindringen og historien viser seg å være svært betydningsfull innenfor litterære studier. I Dessingués innledning til artikkelsamlingen Flerstemte Minner leser vi at både Mikhail Bakhtin og Paul Ricoeur viser til det abstrakte begrepet fortiden (Dessingué 2010:10f.). For begge er fortiden en interaksjon mellom tekst og leser. Sammen danner disse elementene en litterær verden som oppstår i møtet mellom forfatterens, tekstens og leserens horisonter. Her er det snakk om den litterære verdenen, som ikke tolkes frem ved hjelp av historisk forskning. Historiske forskninger viser på sin side til en objektiv sannhet, hendelser som faktisk har funnet sted. Relasjonen mellom den litterære fortiden og mottakeren fører til en aktiv utvidelse av leserens bevissthet. I den forstand kan vi si at minner ikke bare rettes mot fortiden. De kan bli en ressurs for fremtiden eller allerede være $\mathrm{i}$ ferd med å skape den (Dessingué 2010:11). Poenget er med andre ord å vise i hvor stor grad minner påvirker subjektets nåtid sammen med dets identitet og posisjon i verden generelt. Denne måten å tenke fortid på hører også til Memory Studies' programrammer. Hos Dessingué leser vi nemlig at: 
Minneforestilling skiller seg fra historiografien. Å fortelle eller å gjenskape minner er ikke det samme som å skrive historiebøker. Hovedforskjellen ligger ikke så mye i sluttproduktet, men i gjenoppdagelsesprosessen, dvs. i "jakten på fortiden". [...] historiografien prøver å organisere kunnskapene om fortiden og å strukturere tiden $\mathrm{i}$ forskjellige perioder, minnefremstilling er et kontinuerlig og dynamisk fenomen, minnene eksisterer fordi de fortsatt er levende hos dem som forteller. (Dessingué 2010:10)

Et annet moment som minneforskning består av, tar sitt utgangspunkt i begrepene glemsel og et spor. Spørsmålene om hva mennesker gjør med sporene eller hvordan de påvirker oss som fortidens levende vitner, peker på at minner ikke er noe man bare husker. De såkalte sporene bør snarere stimulere vår selvutvikling og føre til nye overveielser hos mottakeren, leser vi videre $\mathrm{i}$ Flerstemte Minner (Dessingué 2010:11). Med andre ord bygger erindringen opp en modifisert virkelighet - noen flersidige eller flerstemmige bilder av det gamle. Det å fortolke denne virkeligheten i et nytt vitenskapelig perspektiv er nettopp en av de opprinnelige oppgavene til minneforskerne.

\section{DIKTETS FØRSTE LESNING}

I fortolkningsarbeidet skal jeg gå gjennom følgene etapper: Jeg skal først se litt nærmere på diktsamlingen som helhet og samtidig undersøke forholdet mellom tittelen og diktets innhold. Videre skal jeg ta for meg "Nocturnes" stemning, presentasjonen av jeg-personen, samt de poetiske virkemildene. Etter en slik førstelesning vil jeg konkludere mine refleksjoner ved å fordype meg i minneproblematikkens diskurs, altså begreper og påstander som har som formål å begrunne bruken av Memory Studies-teori i forhold til Saabye Christensens debutdikt. Denne rekkefølgen skal føre leseren til en bedre forståelse av hvilket ståsted det lyriske jeg-et egentlig befinner seg i.

Som sagt stammer "Nocturne" fra smalingen Historien om Gly. Hele boken forteller om livet til den voksende Gly, og den berører først av alt hans problemer med å oppfylle de krav verden stiller. Diktene synes å være fulle av motvilje mot de etablerte samfunnsrammene som et enkeltindivid er tvunget til å eksistere innenfor. Historien om Gly er delt i to, hvor den første delen er en sekvens med korte prosaaktige tekster som til sammen gir oss et omriss av Glys oppvekst og hans ensomme tilværelse. Gutten bestemmer seg for å slutte med sin sørgmodige tilværelse og begår selvmord - han kaster seg ut av vinduet. Samlingens andre del heter "Glys efterlatte dikt" og består av små lyriske stykker, som Atle Næss kaller "enkle og poetiske øyeblikksbilder" (Næss 1993:2). Siden "Nocturne" er plassert nær bokens slutt, ser det ut til å høre til Glys autobiografiske ettertanker, eller eventuelt å være en slags oppsummering av guttens tapte liv. Generelt sett kan vi si at Historien om Gly 
preges av melankolsk, nesten depressiv stemning, hvor private ettertanker om heltens for-, nå- og fremtid settes sammen med andre dikt om tilfeldige personer og steder som Gly har støtt på i sin korte tilværelse.

Tittelen viser til ordet nocturne (fr. nocturne, nattlig) i betydningen en liten musikalsk komposisjon med røtter i romantikken, og som mest av alt er preget av nattstemning og sentimentalisme (Scholes 1936:691). Natten symboliserer her en slags stimulans til drømmer og drømmelignende situasjoner. Som sjangerbetegnelse ble nocturne innført av den irske komponisten John Field, men det var Frédéric Chopin som gjorde den til en mindre sentimental form, snarere full av savn, gåter og redsel (Muchenberg 1966:79f.). I Saabye Christensens dikt har vi nettopp å gjøre med den type urovekkende stemninger som samtidig fører til jeg-personens (selv)refleksjon.

"Nocturne" er delt i to asymmetriske deler. I den første uttaler det talende jeg sin rådløshet overfor tidens nådeløse strøm som subjektet plutselig blir klar over. Tidens dynamikk uttrykkes ved hjelp av tallrike virkemidler som blant andre sammenligningen "sekundene/ er som tusenben" og "årstidene/ har sjumilstøvler på". For øvrig blir det svært iøynefallende at det tidsmessige fremstår som noe destruktivt, og dermed finnes det ingen vei tilbake til fortidige opplevelser, tilstander og hendelser som subjektet nevner i fortsettelsen av diktet. Det er også verdt å peke på bruken av tidsadverbialer som danner en synlig ramme omkring det som jeg-et henviser til. Vi leser blant annet at: "Speilet jeg så meg i forleden ${ }^{2}$ er knust idag", og "Barnet vi drømte om inatt/ skal begraves $i$ morgen". Det kommer altså til syne at jeg-ets drama har sine kilder i noe uopprettelig. Dette bekreftes for $\emptyset$ vrig av en bestemt bruk av verb og adverb. Ord som 'å rive', 'å forlate', 'å flytte', og mest av alt 'å begrave' gir leseren et inntrykk av noe lukket, altså fortiden jegpersonen ikke lenger har tilgang til. Et annet moment som dessuten bryter med tekstens helhetlige form, er de to midtversene med enderim: "Jeg våkner brått/og tre år har gått". Saabye Christensens valg av akkurat dette virkemiddelet er sannsynligvis ikke tilfeldig. Rimparet tyder samtidig på flere aspekter - først og fremst blir det tidsdynamiske igjen betont. Det er imidlertid også noe heftig i denne prosessen når jeg-et vekkes på et ubestemt tidspunkt. Det talende jeg-et oppdager plutselig at det har mistet dager, måneder og til sammen tre år av sitt liv, uten å huske noen hendelser som har skjedd i denne perioden. Heftigheten synes dessuten å vekke en slags urolig tilstand hos jegpersonen, og den $\varnothing$ delegger samtidig subjektets etablerte eksistens. Tidens ustoppelige og krasse forløp fører til følelsen av tomhet. Dette blir særlig synlig i møtet med den drastisk verbaliserte beskrivelsen av jeg-ets minner og det tidsmessige. Jeg-et synes å ville beholde det gamle i sitt indre og rundt seg

\footnotetext{
${ }^{2}$ Mine kursiveringer.
} 
selv, men betegnelser som blant andre tusenben tyder på at tiden flyr blindt fremover uten å etterlate seg noen følbare spor.

Her er det også viktig å rette oppmerksomheten mot tre relevante ord begreper som dukker opp i diktets første strofe, nemlig 'et speil', 'et hus' og 'krig'. Alle tre, samt deres epiteter, fører til dypere forståelse av jeg-personens aktuelle tilstand. Det knuste speilet kan riktignok ikke settes sammen igjen, krigen som man en gang demonstrerte mot tar slutt og blir etter hvert glemt. Spenningen markerer seg også i det kollektive elementet som rommes i forbindelse med begrepet hjem. Jeg-et minnes sitt hus, men tempusbruken sier ingenting om subjektets bestemte situasjon. Ordet hus peker på noe kollektivt, altså nærværet av andre mennesker - ikke minst familie som jeg-personens ettertanker knyttes til. Noe tragisk finner vi også i niende vers, hvor vi leser at den talendes bosted "er revet når jeg kommer hjem". Omvendt er viljen til å bevare de gamle forholdene klart synlig, men det er tidens forløp som gjør det umulig å komme tilbake til det som var. Med dette forstår jeg altså at jeg-et savner det slags fotfeste som samtidig legger grunnvollen for dens identitet. For øvrig er det også krigen som regnes for å være en hendelse som har berørt flere enn bare én person. Med andre ord blir den upresise konflikten en del av både en objektivt og subjektivt opplevd fortid.

Et annet moment som henviser til det kollektive, er versene "barnet vi drømte om inatt/ skal begraves i morgen", hvor bruken av pronomenet $v i$ betoner minnets fellesskap. I det talende jeg-ets fortid fantes det nemlig noen som subjektet hadde et nært forhold til, og dette var sannsynligvis noen den talende ville bygge sitt fremtidige liv sammen med. Barnets skikkelse er samtidig et tegn på livets mening, for barnet forbindes vanligvis med unge menneskers drømmer om å ta skritt fremover mot det voksne liv. Jeg-ets ønske om å ha en etterkommer medfører et bilde av en stabil og harmonisk fremtid. Visjonen sluttes likevel på en svært brutal måte med å sette drømmen opp mot verbet 'å begrave'. Her har vi nemlig å gjøre med sammenstillingen av et blomstrende liv med et brått tap, som resulterer i jeg-ets tomhet og dets såre ensomhet. Diktets siste strofe viser imidlertid at subjektet vandrer helt alene, og dets erindring er begrenset til det individuelle rommet.

Den siste strofen står i tydelig motsetning til diktets første del. Forskjellen i tempusbruk og antall verslinjer antyder spenningsløsning og medfører en slags oppsummering av subjektets indre tilstand. Den talende uttrykker sine refleksjoner i presens, og det betyr at etter å ha påkalt noen fortidige følelser og hendelser, kommer han tilbake til nåtiden for å svare på spørsmålene hvor er jeg og hvem er jeg egentlig $i$ dag. Omvendt leter jeg-et etter definisjonen av "her og nå" med følgende ord: "Og selv/prøver jeg å gå rett/gjennom gatene". Sagt på en annen måte er dette et forsøk på å gjøre sitt liv ordentlig og forklarlig, men subjektets $\emptyset$ nsket kan ikke lykkes - det mangler et fundament $\mathrm{i}$ form av å ha fortid. Den imaginerte veien vil aldri bli rett, siden den talende 
sammenligner sin bevegelse med fuglens hopp. Denne similen kan for $\varnothing$ vrig peke på jeg-ets kaotiske skritt, hvor jeg-personen synes å gå både uten å ha et visst mål og uten å velge en bestemt retning. På den annen side ser vi subjektets klart verbaliserte håp om å etterlate seg noen spor, noen tegn på sin tilværelse. Det poetiske bildet av en liten fugl oppfattes vanligvis også som en parallell til noe spedt og uvarig. Til slutt viser det seg at man heller ikke kan forvente en eller annen fortsettelse av jeg-ets historie, for merkene han har etterlatt seg, avbrytes på et ubestemt Øyeblikk og sted: "Men mine spor er som fuglens:/små hopp/plutselig borte". Jeg-et søker steder og faste referansepunkter, for de gir ham et inntrykk av stabilitet - røtter, og de kunne sannsynligvis hjulpet ham med å gå videre den rette veien. Fraværet av slik stabilitet blandes med forventninger, glemsel og erindring. Vi kan sammenligne tidens dynamikk med noe destruktivt, altså med noe som ødelegger både minner, identitet og fremtid. Sagt på en annen måte kan subjektet ikke beholde sitt fotfeste. På grunn av tidens strøm mister det meningen med sin eksistens. Til tross for at den talende prøver å markere sine spor, blir de borte skitt etter skritt, hvor ordet borte i dette tilfellet kan knyttes til glemselsprosessen.

Selv om diktets språk nærmer seg dagligtale, og bruken av diverse litterære virkemidler heller ikke synes å være primære for "Noctures" helhetlige struktur, er det verdt å understreke Saabye Christensens måte å gjøre hverdagslige gjenstander til den symbolske uttrykksformer, som er rike på tvetydige undertoner. Avgjørende her er nøkkelord som 'et speil', 'et hus', 'et barn' og 'spor', for de lar oss gå dypere inn i fortolkningsprosessen. For å unders $\varnothing$ ke forholdet mellom diktets første lesning og et begrepsapparat hentet fra Memory Studies, vil jeg analysere disse substantivene ut fra minneproblematikkens perspektiv.

\section{FORTOLKNINGEN I LYS AV MINNESTUDIENES UTVALGTE BEGREP}

Vi skal ta utgangspunktet $i$ Aristoteles sine refleksjoner om erindringsfenomenet. Grunnen til det er ikke bare det faktum at de antikke teoriene la grunnlaget for utviklingen av studiene om hukommelsen. Ved å støtte seg på Aristoteles' undersøkelser kan man dessuten oppnå en bedre forståelse av det lyriske jeg-ets indre tilstand. I sitt velkjente verket Poetikk var Aristoteles opptatt av diverse prosesser som foregår innenfor erindringen. Han legger nemlig frem påstanden om at når hukommelsen aktiveres, signaliseres det alltid i sjelen at man tidligere har hørt, sanset eller tenkt en gjenstand (Aristoteles 2007:48). Omvendt kan vi påstå at alt som jeg-personen minnes, 
nevner og beholder i sinnet, danner en svært viktig del av hans identitet og påvirker samtidig jeg-ets aktuelle situasjon.

De aristoteliske unders $\varnothing$ kelsene går likevel enda dypere og retter søkelyset mot to begreper som er blitt primære for videre forskning på minnemekanismene. I sitt nevnte verk skiller filosofen mellom mnēmē og anamnēsis (Ricoeur 2005:31). Mnēmē er for Aristoteles en uventet affekt som ofte genereres av andre hendelser eller følelser, og hvor et enkelt minne oppstår nettopp som en følelse. Sagt med andre ord kan minner dukke opp uten at man prøver å gjenkalle dem. Dette er snarere en ubevisst prosess som vanligvis er avhengig av forskjellige slags stimuli, altså for eksempel en lukt, en smak, en lyd, en tekst, et sted. Det er slike ting som fører til at ethvert menneske er i stand til å oppleve et uønsket minne (Dessingué 2010:10). Den andre kategorien - anamnēsis - synes å være en bevisst tilstand, og den oppstår som følge av en menneskelig anstrengelse. Oftest er anamnēsis en aktiv og personlig gjenoppdagelsesprosess. Det er altså en handling som genereres $\mathrm{i}$ et koherent forhold til ens vilje og behov for å bevare noe eller noen i sine egne minner for å påkalle disse bildene på et bestemt tidspunkt seinere. Videre skriver Aristoteles at det som kjennetegner hukommelsens natur, er at det å ha et minne i sinnet (når man akkurat er på jakt etter dette) er viktigere enn varigheten av minnets innhold (2007:47).

I "Nocturne" har vi nettopp å gjøre med anamnēsis-kategorien, for subjektet synes å liste opp gamle momenter og steder fra sitt liv. Selv om minnene virker litt uskarpe og upresise på grunn av blant annet mangel på konkrete navn, opplever vi den første strofen som jeg-ets bevisste påkalling av det gamle. Samtidig synes minnene å være ganske kaotiske fordi de stadig blir utsatt for tidens destruktive påvirkning. Hvis man likevel har i tankene Aristoteles sin påstand om at det å beholde fortidens bilder er viktigere enn deres varighet, ser man tydelig at rester av jeg-ets erindring er fast forankret $\mathrm{i}$ dets indre $i$ en eller annen form.

Fortolkningen av ordet hus bygger jeg først og fremst på Paul Ricoeurs romlighetsteori som finnes i hans berømte verk La mémoire, l'histoire, l'oubli (2000). Her berører Ricoeur mange problemer som synes å være relevante for den moderne diskursen innenfor minneproblematikken, deriblant begrepene romlighet (Ricoeur, 2005:197), ${ }^{3}$ det tidsmessige og glemsel. Ricoeur retter oppmerksomheten mot forholdet mellom fysisk plassering og ens individuelle minneevne, og omvendt en slags mental tilknytning til et sted. I begynnelsen av kapitlet Dokumentasjonsfase: arkivert minne (Ricoeur 2005:195) ${ }^{4}$ leser vi nemlig:

\footnotetext{
${ }^{3}$ Siden La mémoire, l'histoire, l'oubli ikke ble oversatt til norsk, benytter jeg meg av den svenske oversettelsen og bruker dermed i noen tilfeller dens norske ekvivalenter.

${ }^{4}$ Svensk: Dokumentationfas: arkiverat minne.
} 
Som utgångspunkt tar vi den kroppens och omgivningens rumslighet som alltid finns med då en hågkomst återkallas (...). Hågkomster av att man bott $\mathrm{i}$ ett visst hus $\mathrm{i}$ en viss stad eller rest i en viss del av världen är särskilt belysande och värdefulla (...); i denna typ av hågkomster förbinds det kroppsliga rummet omedelbart med omgivningens rum (...). (Ricoeur 2005:197)

Ricoeur jevnfører romslighetens kroppslige element med Odyssevs sin sjøreise hjemover til Itaka. Påstanden hans går nemlig ut fra tesen om at både det å ta plass og omplassering er de primære aktivitetene som nettopp gjør plassen til noe man nesten desperat søker seg til. Mangel på slike verdier kan kun føre til forferdelse, selvødeleggelse og fornemmelse av Unheimlichkeit, altså en slags forsmak på både fysisk og indre tomhet. I versene åtte og ni i diktet har vi akkurat å gjøre med den type uro som det lyriske jeg-et opplever ved å komme tilbake til sitt revne hus. Hjemmet, i betydningen subjektets forankring, forsvinner plutselig og etterlater seg samtidig følelsen av noe tapt. Jeg-personens drama kan for øvrig poengteres ved å se nærmere på Davis Harveys genus loci-teori. I denne er det snakk om hvor sterkt "stedets ånd" forandrer vår oppfatning av ordet hjem: "Gjennom 'stedets ånd' blir house til home" (Saryusz-Wolska 2011:138). Antropologer hevder også at man bør betrakte vanlige bygninger, hus og leiligheter som et relevant forskningsmateriale når det gjelder menneskets sosiale og kulturelle natur. Poenget er å oppfatte hjem som et sted hvor beboernes minner samles og bevares. Det lyriske jeg-et har mistet sitt hus som i dette tilfellet assosieres med subjektets stabilitet og er et viktig spor av det tidligere livet.

Huset samler jeg-ets minner og hendelser, men det er ikke bare bostedet som innebærer så sterke undertoner $\mathrm{i}$ fortolkningen av minneelementet $\mathrm{i}$ "Nocturne". Aleida Assmann er en annen forsker som i sine teorier omhandler noen aspekter av stedsproblematikken, især i et litterært og ofte historisk preget perspektiv. Om hukommelsesrom leser vi blant annet i boken Erinnerungsräume (1999), hvor Assmann legger vekt på det metaforiske aspektet ved undersøkelser av minnerommet. If $\varnothing$ lge henne kan objekter og artefakter som tilhører et bestemt rom, være "minnebærende". Som eksempel bruker hun her henvisninger til kirkegårder, biblioteker, arkiver og monumenter, men for diktets skyld knytter jeg denne teorien til ordet speil. Med versene "speilet jeg så meg i forleden/er knust idag" forstår vi at det lyriske jeg-et som speiler seg i gjenstanden, var full av fortidige erfaringer, minner og opplevelser. Denne speilvendte skikkelsen forsvinner likevel helt ugjenkallelig, uten å etterlate seg noen spor av tidligere nærvær. Samtidig med ødeleggelsen mister den talende altså en del av seg selv - en del av sin identitet, for i dette tilfellet kan speilet snarere betraktes som en metafor for subjektets minnebilde. 
Det er også viktig å stille spørsmålet om det finnes noen midler som hjelper oss med minnebevaringsprosessen. Assmann prøver å gi et konkret svar ved å introdusere begrepet der Stabilisator von Erinnerungen. Ifølge Assmann det er språket som regnes for den viktigste formen for hukommelsens stabiliserende kraft:

An erster Stelle wäre hier unbedingt die Sprache zu nennen. Die Sprache ist der mächtigste Stabilisator von Erinnerungen. An das, was wir einmal versprachlicht haben, können wir uns viel leichter erinnern als an das, was nie zur Sprache gefunden hat. (Assmann 1999:21)

De språklige tegnene fungerer nesten som navn. På dette punktet vil jeg henvise kort til barnets skikkelse som det lyriske jeg-et minnes på slutten av første strofe. Det å gi noe et navn hjelper oss med å gjenkalle de fortidige gjenstandene og saksforholdene. Gjennom språket stabiliserer og sosialiserer ethvert individ sine minner. Det talende jeg-et synes enten å ikke legge vekt på å konkretisere og verbalisere sine minner fullstendig, eller han har bare glemt navn på steder og figurer. Dette er trolig grunnet tidens gang som medfører enda mer $\varnothing$ deleggende konsekvenser for de gamle opplevelsene. Et annet alternativ kan være at jeg-et helt bevisst utelater navngiving, for dette intensiverer den ubehagelige følelsen av tomhet. Det eneste vi helt sikkert kan gjenta etter Assmann er at uten navngiving mister man etter hvert sine minner, slik at steder og gjenstander ikke lenger tilhører ens fortid og blir glemt.

\section{ORD TIL AVSLUTNING}

"Nocturnes" stemning preges utvilsomt av følelsen av noe ugjenkallelig. Gjennom å påkalle fortiden viser det lyriske jeg-et et sterkt behov for å etterlate seg noen følbare spor av sin tilværelse. Dette kan, som sagt, ikke lykkes på grunn av tidens ødeleggende aktivitet. Konklusjonen er altså klar uten å forankre sin nåtid i det gamle livet, kan det talende jeg-et ikke feste seg $i$ et eller annet mentalt og fysisk sted. Minnene som litt etter litt forsvinner, har utelukkende mening i sammensetningen med "her og nå", selv om dette heller ikke kan defineres. Fortiden dukker omvendt opp som det uunngålige elementet som følger av subjektets fortsatte livsløp og utvikling. Det er imidlertid forgjeves å lette etter skyld for denne situasjonen hos subjektet den destruktive kraften er tiden selv. Dens ustoppelige gang fører til et tydelig brudd på linearitet og frembringer kaos som samtidig behersker tilværelsen til den talende. Paradoksalt nok er dessuten det faktum at selv om jeg-et har beholdt noen minner, er det heller ikke i stand til å bruke dem for å utvikle sitt fremtidige liv.

Bruken av Memory Studies' teorier betoner også et annet problem som samtidig oppsummerer jeg-personens tilstand i diktet. Innledningsvis la jeg 
nemlig merke til måten man kan interpretere spor-tematikken på. Etter å ha gått ut fra tesen om at de såkalte sporene ikke bare oppfattes som en del av noens erindring, men at de også har en betydelig innflytelse på subjektets videre selvutvikling, kommer vi til følgende slutninger: På den ene side er det lyriske jeg-et på jakt etter noen spor fra fortiden, men på den andre side viser det en sterk vilje til å etterlate seg noe som kan huskes. Tross et mislykket fors $\varnothing \mathrm{k}$ på å bli en del av historien, er det nettopp dette behovet som trolig kunne gi subjektets tilværelse en mening.

I denne artikkelen har jeg påvist hvordan man kan utvide fortolkningen av Saabye Christensens "Nocturne" med fokuset rettet mot minneproblematikken. De ovennevnte teoriene innenfor Memory Studies er kun et middel til å unders $ø$ ke sammenhenger mellom det teoretiske og jeg-personens lyriske situasjon. Imidlertid blir den slags lesemåte enda mer interessant hvis man ser nærmere på forfatterens forhold til erindringstematikken. Problemet som ble tatt opp i arbeidet kan vel anses som et forslag på videre og omfangsrikere undersøkelser av Saabye Christensens ikke-lyriske tekster og deres forbindelser med fortid og minner. Sitatet hentet fra intervjuet med forfatteren betoner igjen hvor viktig det tidmessige er i hans generelle motivutvalg: "Utgangspunktet er vel at jeg ser tilbake, samtidig som jeg prøver å identifisere meg , prøver å finne tilbake til hvordan det var den gang" (Hovdenakk 1993:17). For å støtte seg på andre litteraturforskere som også har lagt merke til den spesielle måten Saabye Christensen betrakter fortid på, vil jeg avslutte mine refleksjoner med Erling Aadlands anmeldelse som kom ut i anledning av utgivelsen Saabye Christensens diktsamling Stempler i 1989: "Men tiden er et problem. For Christensen blir det ekstra problematisk fordi han nesten alltid fikserer tiden til romlige betydninger (...)" (Aadland 2004).

\author{
Nocturne \\ Sekundene \\ er som tusenben \\ og årstidene \\ har sjumilstøvler på. \\ Speilet jeg så meg i forleden \\ er knust idag. \\ Jeg våkner brått \\ og tre år har gått. \\ Huset jeg forlot i morges \\ er revet når jeg kommer hjem. \\ Krigen jeg demonstrerte mot igår \\ er flyttet til et annet land idag. \\ Barnet vi drømte om inatt \\ skal begraves i morgen.
}

Og selv

prøver jeg å gå rett

gjennom gatene.

Men mine spor er som fuglens:

små hopp,

plutselig borte.

(Christensen 1976:77) 


\title{
BIBLIOGRAFI
}

Aadland, Erling. 2004. Ikke fred over disse minner. I: Haagensen, Nils-Øivind (red.). Lars Saabye Christensen: forfatterhefte. Oslo: Biblioteksentralen.

Aristoteles. 2007. Om hukommelse og genkaldelse,. Overs. og kommentar D. Bloch. København: Museum Tusculanums Forlag.

Assmann, Aleida. 1999. Erinnerungsräume: Formen und Wandlungen des kulturellen Gedächtnisses. München: Beck.

Christensen, Lars Saabye. 1976. Historien om Gly. Oslo: Cappelen.

Dessingué, Alexander (red.). 2010. Flerstemte minner. Stavanger: Hertervig Akademisk Forlag.

Hovdenakk, Sindre. 1993. Dikt med rock, rytme og refreng. Aftenposten (12.05.1993).

Kverndokken, Kåre. 2001. Lars Saabye Christensen - et forfatterskap. Oslo: Gyldendal Undervisning.

Larsen, Turid. 2004. Å dikte er en risikosport. I: Haagensen, Nils-Øivind (red.). Lars Saabye Christensen: forfatterhefte. Oslo: Biblioteksentralen.

Næss, Atle. 1997. Lars Saabye Christensen; et forfatterportrett. Oslo: Biblioteksentralen.

Muchenberg, Bohdan. 1966. Pogadanki o muzyce cz. 2. Kraków: PWM.

Ricoeur, Paul. 2005. Minne, historia, glömska. Overs. E. Backelin. Göteborg: Daidalos.

Saryusz-Wolska, Magdalena. 2011. Spotkania czasu z miejscem. Studia o pamięci i miastach, Warszawa: Wydawnictwo Uniwersytetu Warszawskiego .

Scholes, Percy A. 1936. The Oxford Companion to Music. London: Oxford Univerity Press.

Vatne, Vidar. 1998. Veier til verke. Om Beatles av Lars Saabye Christensen, Oslo: Ad Notam Gyldendal.

Vold, Jan Erik. 2004. Det lakoniske besvær. I: Haagensen, Nils-Øivind (red.). Lars Saabye Christensen: forfatterhefte. Oslo: Biblioteksentralen.

\author{
Aleksandra Regina Wilkus \\ Uniwersytet im. Adama Mickiewicza w Poznaniu \\ Katedra Skandynawistyki \\ Collegium Novum \\ al. Niepodległości 4 \\ 61-874 Poznań \\ Poland \\ aleksandra.wilkus@amu.edu.pl
}

